\title{
Karl Heim se verstaan van ruimte in die debat tussen die teologie en natuurwetenskap
}

\author{
J Buitendag \\ (Universiteit van Pretoria)
}

\section{ABSTRACT}

\section{Karl Heim's understanding of 'space' in the debate between theology and natural sciences}

This article gives a brief synopsis of Karl Heim's understanding of space in terms of its present and past spheres and the overarching metapolar sphere of God where all dichotomies are being resolved. The rather classical booklet of Edwin Abbott, 'Flatland', is used as an introduction to indicate the importance of understanding reality in terms of dimensions and the expanding thereof. It makes sense to consider this as a point on the agenda in the dialogue between theology and natural sciences. The author points out thatHeim's concept of space finds its way both in philosophy and theology inter alia in the works of Deleuze and Kasper respectively.

\section{INLEIDING}

In 'n klassieke boekie, Flatland, wat sy tyd ver vooruit was, daag die outeur, Edwin A Abbott ([1884] 1998), onderwyser en predikant in die Cambridge tradisie, sy leser uit om die werklikheid nie alleen in terme van drie dimensies te verstaan nie, maar polidimensioneel. Die eerste helfte van die boek sou as ' $n$ sosiale satire bestempel kon word waarin onder andere determinisme en gelatenheid ernstig aan die kaak gestel word. Die boek het as oriënteringspunt ' $n$ tweedimensionele wêreld met inwoners wat weier om die derde dimensie te erken of selfs net te bedink. In hierdie "Vlakkeland" is alle bestaan beperk tot bloot lengte en breedte. In tweedimensionaliteit word alles as òf ' $n$ punt òf ' $n$ lyn waargeneem. Mense bestaan dus as platvlakke soos poligone, driehoeke en sirkels. Hoe groter die getal hoeke van ' $n$ individu, hoe hoër sy status. Derhalwe moet mense mekaar in hierdie wêreld fisies aanraak ten einde die ander se getal hoeke (waarde) te bepaal. Die reën kom uiteraard ook nie van 'n bo af nie - so ' $n$ dimensie bestaan nie - maar altyd van noord na suid.

Die tweedimensionele verteller in die boek - op die titelblad ook genoem A Square - sien in 'n visioen Lineland, die wêreld van slegs een dimensie. Die regent van hierdie wêreld het geoordeel dat alles een reguitlyn is en so ook alle ruimte: "Outside his World, or Line, all was a blank to him; nay, not even a blank, for blank implies Space; say rather, all was nonexistent” (Abbot 1998:66). Alles kan in hierdie wêreld 
uiteraard net waargeneem word as 'n enkele punt. Links en regs bestaan nie, ook nie bo en onder nie, slegs vorentoe en agtertoe op die een en selfde lyn. Deur dwars te beweeg, word daar oorgegaan in 'n meerdere dimensie en word die voorwerp dus onkenbaar vir die laere dimensie. Die perspektiwiese middelpunt word hiermee die kriterium vir die werklikheid en tyd weer ' $n$ funksie van beweging.

Maar die tweedimensionele verteller in die boek beweeg nie net afwaarts in dimensies nie, maar ook opwaarts. Deur bloot die rekenkundige reeks uit te brei en die eksponent telkens te vergroot, word ' $n$ volgende dimensie voorgestel (Abbot 1998:88). Eendimensionaliteit word verstaan as ' $\mathrm{n}$ reguitlyn met dus 2 punte. Tweedimensionaliteit word voorgestel as byvoorbeeld ' $n$ vierkant met 4 punte en driedimensionaliteit word weer voorgestel as ' $n$ kubus met 8 hoeke. Anders gesê, ' $n$ punt het geen sye nie, ' $n$ lyn weer het net 2 , ' $n$ vierkant 4 en ' $n$ kubus natuurlik 6. Dus is die reeks $\{0,2,4,6\}$.

In 1920 het daar in die hoog aangeslane natuurwetenskaplike tydskrif Nature 'n artikel verskyn met die titel "Euclid, Newton and Einstein" waarin breedvoerig na Flatland verwys is. Hierin word Einstein se twee relatiwiteitsteorieë (1905 en 1917) bespreek, asook tyd as synde die vierde dimensie van die werklikheid. Tyd is nie bloot ' $n$ additief in die werklikheidsverstaan soos nog ' $n$ plank bo-op ' $n$ ander nie, maar is sodanig geïntegreer met driedimensionele bestaan dat dit ruimtelik kan verander as gevolg van beide gravitasie én die posisie van die waarnemer. Die artikel vergelyk dan tyd-ruimte as die hipotetiese vierde dimensie soos wat 'n platvlak na ' $n$ kubus toe kan verander. 'n Sfeer, byvoorbeeld, sal in tweedimensionaliteit bloot as ' $n$ sirkel waargeneem word - eers net as ' $n$ punt, dan groter en groter tot sy volle grootte, en dan weer kleiner en kleiner tot slegs ' $n$ enkelpunt.

Heim (1949:147) het in hierdie selfde rigting gedink. ' $n$ Bewegende punt bewerk ' $n$ lyn, ' $n$ bewegende lyn ' $n$ vierkant en ' $n$ bewegende vierkant weer, bewerk ' $n$ kubus. Waarom moet dan nou hier halt geroep word, vra hy. Kan die kubus nie ook met sy agt hoeke skuif na 'n vierde dimensie met sestien hoeke nie? Waarom kan daar nie so voortgegaan word nie? Polariteit word (Hegeliaans) opgehef deur die byvoeging van 'n meerdere dimensie. Dit bevat vir Heim die moontlikheid om hiermee die ontologiese brug tussen geloof en rede te span.

\section{Die dialoog tussen geloof en rede}

Dit was vir Karl Heim (1874-1958) - in lewe professor in Dogmatiek eers in Münster en later in Tübingen - van die uiterste belang om die geloofwaardigheid van die Christelike geloof binne hierdie wêreld te behou. Die Christelike geloof mag hom nie in een of ander ghettobestaan 
terugtrek nie. Hierdie gesprek met die natuurwetenskap is juis ook die rede waarom teologie aan ' $n$ universiteit gedoseer moet word. Die gelowige het immers ook ' $n$ "intellektuele gewete" en volstruispolitiek is allesbehalwe die antwoord. Die denkmoontlikheid van die gelowige mag nooit verontagsaam word nie. Daarom noem Heim sy hoofwerk, Der evangelische Glaube und das Denken der Gegenwart, wat in ses volumes tussen 1934 en 1952 verskyn het. Hiermee bedoel hy (Heim 1931:16) ook die "Wissenschaft vom Ganzen". Die teikengroep van sy werk is daarom ook diegene wat hulle op die brug tussen kerk en wêreld bevind (Heim 1935:6) en die filosofie vorm hier die gemeenskaplike taal.

Waar die koppelwoord en tussen geloof en rede ernstig opgeneem word, daar is filosofie, sê Heim (1926:458). En merkwaardig genoeg, wil ook hý (soos Hawking en Barrow vandag by name) alles in één enkele formule vasvang (Heim 1926:14). Dit beteken nie dat Heim die bevindinge van die natuurwetenskap wou populariseer nie, nee, hy wou slegs aantoon dat geloof en rede sáám die werklikheid beskrywe en dat die een dus nie sonder die ander kan funksioneer nie. Die een begin waar die ander ophou en lê dus op mekaar se grense. Soos die negatief van ' $n$ foto deur sy positief bruikbaar gemaak word, so geld dit van geloof en rede. Die teologie se uitdaging lê dus daarin om God nòg deïsties uit die wêreld te verwyder nòg panteïsties in die wêreld te laat opgaan (Heim 1934:47). Daarom moet 'n dimensie in die werklikheid blootgelê word wat buite die natuurwetenskap, maar binne die wêreld teenwoordig is. Die gesprek moet met die natuurwetenskap dus sowel die nieobjektiveerbare $e k$ as die teenwoordigheid van God kan aantoon (Heim 1949:35).

Die polariteitsbeginsel - wat Heim (1949:175) ook kollektief ' $n$ ruimte as sodanig kan noem - bepaal dat die werklikheid altyd in spanning verkeer en dat die mens dan in ' $n$ ossillasie-proses tussen hierdie twee pole vasgevang is (Heim 1935:27). Of die mens verval in ' $\mathrm{n}$ relativisme waar hy deur die breë stroom meegesleur word (Heim 1935:59), of die mens verval in ' $\mathrm{n}$ positivisme. Laasgenoemde is die vashou aan sekere absolutes en daarom ook nihilisme in die ergste graad (Heim 1949:260). Dit lei uiteraard na 'n materialisme. Die Christelike geloof moet dan nou hierdie omvattende wêreldbeeld van sekularisme vervang met ' $\mathrm{n}$ dinamiese een. Dit gebeur wanneer elke verdere dimensie die vorige een se polariteit ophef en hierdie dimensie dan die moontlikheid van die "onmoontlike derde" van twee pole word.

\section{Ruimte}

Met die begrip ruimte, wat Heim soms sfere of soms dimensies noem, bedoel hy nie die begrip ruimte van die Euklidiese wiskunde nie. Aangesien ons hier met geen konkrete ruimte te doen het nie, is dit ook 
nie meetbaar, aanskoulik of voorstelbaar nie. Dit is ' $n$ metafisiese grootheid. Hiermee is reeds gesê dat ruimte nie suiwer in die objektewêreld geleë is nie; dit is ook nie suiwer in die gedagte van die denkende subjek nie, maar in die verhouding daartussen (Heim 1949:148). Dit is soos twee pole wat verbind en 'n elektriese kragveld tot gevolg het. En alleen in hierdie ganse subjek:objek-verhouding kan die ruimte gefundeer word (Heim 1949:150). Tweedens is ' $n$ ruimte of dimensie ook oneindig, ' $n$ kontinuum. Die feit dat daar nie-euklidies gedink word, maak verskeie geometrieë moontlik: 'n reguit lyn deur 'n gegewe punt het nie net twee rigtings nie ([1904]1980:70); die somtotaal van die hoeke van 'n driehoek kan meer as $180^{\circ}$ wees; en 'n reguit lyn word nie meer gedefinieer as die kortste afstand tussen twee punte nie. ' $n$ Tydpunt is vir Heim twee lyne wat mekaar kruis, terwyl ' $n$ ruimtepunt die gevolg is van ' $n$ derde kontinuum wat daardeur beweeg. Ruimte ontstaan dus wanneer tydpunte wissel. Daar kan nou gesê word dat "der Raum ist eine Zeit zweiten Grades” ([1904]1980:77). Dit beteken dat tyd ook vorm bepaal. Heim illustreer dit aan die hand van 'n plat skyf met die verskillende kleure in onderskeie sektore; hoe vinniger die skyf nou om sy eie as tol, hoe meer verander en vervaag die individuele kleure tot alles uiteindelik dieselfde kleur is. Hieruit formuleer hy dan 'n stelreël: "hoe korter die tyd, hoe minder die onderskeidinge". Die derde dimensie van die kubus is in wese bloot net die verhouding tussen een- en tweedimensionaliteit en wat altyd deur tyd gekonstitueer word. Wanneer 'n kubus sy syaansig na die waarnemende subjek wend, is die bo- en onderkant daarvan in een punt saamgetrek en word slegs ' $n$ vierkant waargeneem, want "een kantepaar is in die onsigbare tydelikheid opgeneem”. Hierdie oënskynlike vermindering van dimensies kan ewenwel omgedraai word en dimensies kan daarby veronderstel word, sonder dat dit natuurlik waargeneem hoef te word. Die tyd bepaal hierdie moontlikheid. In ons objektiveerbare wêreld neem ons dimensionaliteit waar as lyne, vlakke en kubusse, terwyl dit onwaarneembaar respektiewelik bestaan as die $e k$, die $j y$ en die onswêreld ([1904]1980:90 ev). Samevattend sou mens dus in die woorde van Kant ([1934] 2000:48-51) kon sê dat vir Heim ruimte 'n intuïsie is wat $a$ priories alle voorstelling voorafgaan. Daarom is dit ook geen konsep nie.

Ten einde die polidimensionaliteit van die werklikheid in te sien, is dit nodig om die grense tussen dimensies te definieer. Eerstens is dimensionale afgrensing geen inhoudelike aangeleentheid nie. Laasgenoemde vind plaas wanneer byvoorbeeld twee perde in dieselfde stal van mekaar onderskei kan word en dus geskei en begrens is (Heim 1934:50 ev). Dimensionale afgrensing is altyd relatief en moet paradoksaal uitgedruk word (Heim 1934:65). Tweedens kom eenheid en verskeidenheid tussen ruimtes nie tot stand omdat grense gedeel word soos die geval met inhoudelike afgrensing nie, maar omdat twee 
kontinuums op dieselfde inhoud betrekking het. Twee aspekte van een en dieselfde werklikheid word dus onderskei soos twee fotograwe wat vanuit verskillende perspektiewe dieselfde gebou fotografeer. Slegs een aspek is op ' $n$ gegewe oomblik vir ' $n$ fotograaf moontlik en waar. Aangesien twee kontinuums ' $\mathrm{n}$ contradictio in terminis is - een oneindigheid duld nie daarnaas nog ' $n$ oneindigheid nie - het ons hier met een en dieselfde werklikheid te doen, alhoewel die eenheid onwaarneembaar is. Derdens het ruimtes ' $n$ unieke struktuur en deelverhouding. Dit kan vergelyk word met die oneindige reguit lyn (eendimensionaliteit) wat aan 'n oneindige plat vlak (tweedimensionaliteit) deelneem om die kubus (driedimensionaliteit) tot gevolg te hê. So bestaan daar dimensionale koördinasie wanneer kontinuums naasmekaar is, en dimensionale subordinasie wanneer kontinuums inmekaar is. Vanweë die feit dat ons hier met kontinuums te doen het, raak dit nie mekaar nie, maar ontmoet dit. Die snypunt 0 behoort dus ten volle aan kontinuum AB, netsoos aan kontinuum CD. Aangesien die rigting van die kontinuums verskil, het elkeen ook 'n unieke aspek van die snypunt, alhoewel dit die algehele waarheid van 0 is (Heim 1934:77). Hierdie snypunt is konstitutief vir ruimte as synde die deelaspek van ' $n$ omvattender ruimte. Laastens word hierdie ruimte nie deur empiriese kennis blootgelê nie. Sintuiglike waarneming dien alleen die beskrywing van inhoude. Soos die rykdom en skoonheid van ' $n$ skildery meer is as die somtotaal van enkelvoudige verfstrepe, so is die dimensionale kennis geheel en al los van waarneming. Ruimte is immers ' $\mathrm{n}$ aprioriese kategorie. Kennis bestaan nou ook van dit wat nie verobjektiveer kan word nie. Kant ([1934] 2000:49) het reeds die twee stappe uiteengesit: transendentale estetika bestaan eers uit isolasie van sintuiglikheid ten einde by empiriese intuïsie uit te kom. Dan word alle sensasie geïsoleer om suiwere intuïsie oor te hou. En dit kan alleen ruimte en tyd wees wat gevolglik oorbly.

Hieruit is dit nou duidelik dat Heim (1934:83) met sy ruimtebegrip, of dan dimensionale kategorieë, die weg wil baan vir die sogenaamde onsienlike werklikheid wat ook die eintlike (vierde?) dimensie kan heet, maar verkieslik as die "binnewêreldse transendensie" bekend moet staan. Keuse hiervoor is geen empiriese oordeel nie, maar ' $n$ eksistensiële beslissing. 


\section{4 "Ich und Du" 1}

Wir sehen: Unsere Stelle, an der wir innerhalb des dreidimensionalen Körperraums auf die unsichtbare Gegenwart des Ich stoßen, das einem andern Raum angehört, ist die perspektivische Mitte, also der sehende Punkt, an dem das ganze Panorama der sich stetig verändernden Körperwelt wie auf einer beleuchteten Bühne vorüberzieht.

(Heim 1949:141)

Die beeld wat ek vanuit my perspektiwiese gesigspunt het, word skielik versteur wanneer ek besef dat ek nie die enigste ek is nie. ' $n$ Tweede ek wat ewe onskeidbaar en onomruilbaar aan sy of haar gesigspunt verbind is, maak sy opwagting, en 'n wêreld met twee middelpunte ontstaan dan (Heim 1949:57)! En dit is presies die rede vir die ónvrede. Daarom beleef ek jou as ' $n$ konkurrent, juis omdat jy ook 'n ek is. Daarom is ' $n$ sowel-as onmoontlik en doem alleen die ongenaakbare en harde óf-óf dit aan my werklikheid op. Ek is immers net ek in soverre ek nie jy is nie ( $A=A$, mits $A$ nie $B$ is nie). Ek is net dit wat jy nie is nie. Hierdie konkurrensie manifesteer ook kollektief tussen groepe, volke, ja ook in die plante- en diereryk. 'n Universele krygstoestand bestaan daarom oral (Heim 1952:123).

In feite beteken dit dat ons met ' $n$ dubbele faset van die werklikheid te doen het. Enersyds word die ek teenoor die jy afgegrens, en andersyds die ek teenoor die dit. Die werklikheid word daar dus as sowel die tweede persoon as in die derde persoon beskou. Die ek-wêreld is die domein van my wil en die dit-wêreld die domein van my kennis (Heim 1949:192). Eersgenoemde is ónobjektiveerbaar en laasgenoemde weer objektiveerbaar. Isoleer mens nou die "ek", het mens dus die onobjektiveerbare ek in die denkbeeldige visier: myself kan ek nie waarneem nie, ek kan dit net wees. Dieselfde geld natuurlik van die jy wat ook ' $n$ onobjektiveerbare syn het wat in verhouding tot die wêreld en tot ander mense staan. Hieruit, lei Heim nou af, bestaan die werklikheid basies uit drie verhoudinge:

- My wêreld tot jou wêreld

- Ek tot my wêreld

- Ek tot jy (U)

$1 \quad$ Hiermee verwys ek na Martin Buber se bekende boek wat graag deur Heim aangehaal word. Mens sou ook die paragraaf n.a.v. Martin Heidegger se "Sein und Zeit” kon beskryf. Heim gee egter 'n tree verder terug as Heidegger se 'Dasein' en 'Mitsein'; die eintlike ruimte lê vir hom juis anderkant die ruimte waarin ek eksistensieel staan en dus van bewus is. So het byvoorbeeld die plantewêreld ' $n$ totaal ander aspek van tyd as die mens. 
Ervaring kom tot stand wanneer hierdie drie verhoudings in kombinasie tree (Heim 1934:89). Dit is ook duidelik dat die laaste verhouding van die drie uniek ten opsigte van die ander is: dit is geheel en al ónobjektiveerbaar in albei pole en het daarom ' $n$ andersoortige synsmodus as dié waar die objekte-wêreld ter sprake is.

Soos die taal bloot die gestalte van die inhoud van byvoorbeeld ' $n$ boek is, is die ruimte uitdrukking van ' $\mathrm{n}$ verhouding tussen twee pole (Heim 1949:150). In die ossillasie tussen hierdie pole "staan" die syn (Heim 1931:63). Die werklikheid par excellence, lê dus duskant die objekte-wêreld en laasgenoemde is bloot die neerslag, die slagveld van die stryd tussen hierdie twee pole in die onsigbare sfeer (Heim 1949:139). Hierdie werklikheid is die ens realissimum (Heim 1949:50).

Hierdie dubbele faset van die werklikheid is aan mekaar verwant soos geloof en rede, die onsienlike en sienlike, wil en kennis. Die eerste ruimte staan bekend as die presensruimte (Heim 1949:69). Dit is die argitek of kunstenaar se ateljee; van hieruit word die empiriese wêreld beplan en gedikteer. Hier bevind die eintlike en ware ek hom. Die tweede ruimte staan bekend as die perfektumruimte (Heim 1949:75). Dit is die empiriese en objektiveerbare wêreld. Dit was die oop toekoms, maar het tot hierdie kenbare verlede gestol. Hede is in 'n sekere sin gelyk aan verlede (Heim 1952:117). Ons sien dus nooit die wêreld hoe dit is nie, maar hoe dit was. Die kykende ek, die kykende jy, en die alsiende God kan hier nie vasgevang word nie.

\section{Die meerdere dimensie van God}

Indien mens die transendensie en immanensie van God in die teologie van Heim nagaan, bemerk mens 'n bepaalde ambivalensie in sy denke op; aangesien hierdie ambivalensie ook kronologies manifesteer, is dit moontlik om van 'n ontwikkeling van die jongere na die ouere Heim te praat. Die eerste visie kan ons die filosofiese en die tweede die teologiese noem. Dit is opmerklik dat Heim in sy ontwikkeling al hoe meer openbarings-positivisties begin dink, en namate sy jare vorder, maak uitdrukkings soos "openbaring”, "wonder”, "Gans Andere”, "spesiale organe", "sluier van die oë", ja selfs die woord "Bybel”, toenemend hulle opwagting. Die opmerklikste en ook die belangrikste begrip wat nuut in sy teologie op die toneel verskyn het, is die van die sogenaamde bópolêre ruimte van God. Eers in die tweede band van sy hoofwerk (Heim 1935:32 ev) maak dit vir die eerste keer sy opwagting en in band ses staan Heim (1952:135-180) vyf en veertig bladsye daaraan af. Dit is hieruit duidelik dat band een ' $\mathrm{n}$ soort van oorgangstadium in sy denke is.

In Weltbild der Zukunft lê die transendensie en immanensie van God in die personale verhouding tussen die ek en die U. Wanneer Heim ([1904]1980:104-117) die wil behandel, lê die immanensie van God vir 
hom daarin dat twee wille, myne en God s'n, harmonieer. Die wilskeuse vir God is die teenwoordigheid van God in die lewe van die gelowige. Die feit dat goddelike en profane wille kan saamstem, bring sekerheid en vestig das Jetzt. Die transendensie van God word egter gewaarborg deurdat God se wil die oneindige en die albeheersende wil is ([1904]1980:262). Die werklikheid is die ontmoeting tussen twee wille waarvan God s'n domineer ([1904]1980:205)².

In sy tussenstadium, wat in band een tot ' $\mathrm{n}$ einde kom, kan Heim nog enigsins hierop voortbou. Kennis kom nou teenoor die wil te staan en terminologies druk hy dit uit met die bipolêre sfere (Heim 1934:192). Die dwingende vraag word ' $\mathrm{n}$ etiese een: wat behoort ek te wil? Ek benodig dus ' $\mathrm{n}$ instansie wat my wil onder regie sal neem ten einde die goed en reg as verlede te laat versteen. Hierdie leiding moet in die primêre ruimte teenwoordig wees (Heim 1934:193). Hierdie instansie moet ook nie identies aan myself wees nie - dan is die norm nog maar my eie; dit moet ook nie uit die voorhande werklikheid stam nie, want dan is dit reeds ' $\mathrm{n}$ resultaat van ' $n$ ander se wil. Die twee moontlikhede is ' $n$ keuse tussen ' $n$ relativum of 'n (skynbare) absolutum. God se transendensie is dan naas bogenoemde die derde moontlikheid. Dit oorkom die polariteitsbeginsel van die werklikheid; Hy is as Skepper teenoor en buite elke pool van die werklikheid. Hy is nòg die begin, nòg die einde van ' $n$ kontinuum. Daarom kan die oplossing van die paradoks ook nie kategoriaal plaasvind nie - en dis wat nou nuut in Heim se denke is - maar ' $n$ beweging moet volvoer word wat totaal andersoortig aan die dimensionale onderskeidings is. God staan immers bo hierdie polariteit. So kom die ossillasie tussen die praesens en die perfektum voor God alleen tot rus. So bly die Skepper van die skepping te onderskei en is die omega ook deur die alfa gevind.

Wanneer Heim later toenemend openbaringspositiwisties neig, is die transendensie van God veel duideliker van die immanensie te onderskei. Die bópolêre ruimte word nou die gangbare terminologie. Enersyds is dit die ruimte waarin God teenoor ons te staan kom. Dit is ' $\mathrm{n}$ Daseinsform buite hierdie polariteit, alhoewel dit nie "hoog bo ons koppe" sweef nie; dis nie ' $n$ verlore paradys agter ons nie en ook nie 'n nostalgiese droom voor ons nie. Die bópolêre ruimte is 'n ruimte soos die kollektiewe polariteit 'n ruimte is (Heim 1949:182). Dit is God se ruimte. Andersyds - en dit is die finale fase van Heim se denke - gaan God nie resloos op in hierdie bópolêre ruimte van Hom nie. Heim kan selfs sê dat God ook nie as ' $n$ tweede ek tot ons kom nie; Hy woon immers in die ontoeganklike lig. Heim (1949:192) maak in hierdie opsig ook die insiggewende opmerking dat hierdie ontmoeting met God ons net "as 'n geskenk in die

2 Ek oordeel dat Heim hier baie na aan die Prosesteologie se denke kom, pertinent die van Hartshorne en Cobb. 
skoot kan val" en kan ons mense vir wie hierdie ruimte (nog) geslote is, nie deur "rasionele argumente of didaktiese tegnieke" tot hierdie dimensie lei nie. Dit gee aan Heim se apologetiek 'n unieke kleur.

\section{Waardering}

Alan Lightman (in Abbott 1998:xiv-xv) het dit reg in sy inleiding dat Flatland ons daag om die werklikheid baie groter en ryker te verstaan as wat die wiskunde en fisika stellig beweer. Schwarz se "superstring" teorie van etlike ruimtelike dimensies, Hawking se teorie dat swartgate dalk tog nie so swart is nie en Guth se teorie oor die eksponensieel uitdyende heelal, bevestig natuurwetenskaplik hierdie wordingsproses na ' $\mathrm{n}$ oop toekoms. Ons kan mos so begrensd dink en werklikheid reduseer aan verifiëring en falsifisering. Heim (1934:75) het hierdie uitdaging om ruimer te dink aanvaar:

Wir müssen mit der Möglichkeit rechnen, daß sich auch der Körperraum einem noch umfassenderen Raum einordnet und daß er innerhalb dieses höheren Ganzen mit anderen Körperräumen, die auf gleicher Stufe stehen, in ein dimensionales Koordinationsverhältnis tritt.

Die sogenaamde "superstring theory" lewer inderdaad opwindende perspektiewe op in terme van die begrip ruimte by Heim. Waar die aanvanklike teorieë op soek is na 'n oorkoepelende teorie van alles (Grand Unified Theory), entiteite as punte met geen uitgebreidheid verstaan het, impliseer superstrings entiteite as lyne of kringe van energie as die basiese elemente (Barrow 1994:129). Dit slaag inderdaad daarin om gravitasie in verband met die ander drie kragte (elektromagnetisme, sterk- en swak nukleêre krag) te bring. Modelle is ook gekonstrueer wat tot soveel as 10 of 11 ruimte-dimensies het. Die probleem is egter dat slegs die eerste drie dimensies van waarde is, die res is vasgevang in 'n kwantum-stolling toe die heelal $10^{43}$ sekondes oud was en dit 'n uitgebreidheid van $10^{33} \mathrm{~cm}$ gehad het! (Barrow 1994:130). Hawking (2001:54) bevraagteken wel die waarde van meerdere dimensies, maar laat die opsies nietemin gretig oop.

Heim se antwoord om hierdie "en" tussen geloof en rede, teologie en natuurwetenskap, te beskryf, bevredig wel in 'n groot mate. Etlike opsies om hierdie verbinding te bewerkstellig, word in die literatuur voorgestel. Ian Barbour (2000) noem 4, Gregersen en Van Huyssteen (1998) identifiseer 6 en Ted Peters ([1997]2000) weer, sien 8 raak! Dit is tog opvallend dat die 5 opsies van Buri, Lochmann en Ott (1976:36-47) nie in die debat juis vermelding ontvang nie. Benewens die vier moontlikhede wat Barbour later ook sou noem, onderskei Ott ten opsigte van die dialogiese verhouding, ook tussen die tangensiële en die 
katalitiese modelle. Dit erken teologie en natuurwetenskap se bestaan en grense, en wel in so 'n mate dat dit invloed op mekaar se onderskeie resultate het, en met die katalitiese aksent daarby, sonder om self te verander. Heim wil nóg 'n metafisika vir die natuurwetenskap ontwerp, nóg 'n fisika vir die teologie. Skeppingsgeloof transendeer vir hom ruimte en tyd en wel in die sin dat die skeppingsgeloof die bopolêre sintese van alles is. ' $\mathrm{n}$ Analogia entis is vir hom dus uitgesluit. Hy is hoogstens bereid om van ' $n$ impuls (Anlaß) in die empiriese wêreld te praat wat die mens na God kan, maar nie noodwendig moet lei nie, en waarvan die uiteinde onvoorsienbaar is. Ja, alleen die openbaring in Christus ontsluit hierdie dimensie (Heim 1935:63).

Wanneer Heim (1960:33) op sy oudag na sy lewe terugskou, lê hy getuienis af van sy bekering na aanleiding van ' $n$ preek van Elisas Schrenk, 'n Swabiese piëtistiese predikant, oor Jesaja 43:18 - "Maar moenie net aan die vroeëre dinge dink en by die verlede stilstaan nie. Kyk, Ek gaan iets nuuts doen, dit staan op die punt om te gebeur...” Heim noem dit die kreatiewe nuwe begin van sy lewe. Dit gaan vir hom dus om ' $n$ beslissing wat geneem moet word (Heim 1951:167). Die breek met die verlede is noodsaaklik en geloof en denke speel hierin die deurslaggewende rol. Die een absolute wat werklik is, is God. Dit hoor Heim reeds in die Eerste Gebod en dit is vir hom die uitgangspunt vir alle geloof. Die filosofiese ruimtes word met Goddelike inhoud gevul en daarvoor is ons “auf Gottes Offenbarung angewiesen” (Heim 1934:226).

\section{$7 \quad$ Slot}

Graham Ward ([1997] 2000: xvii-xxii) beskryf tyd, ruimte, liggaamlikheid en taal as die boustene van die postmodernisme. Dit was eers sedert laat in die Middeleeue dat ruimte as die liniêre afstand tussen twee of meer punte of objekte verstaan is. Voorheen was dit bloot simbolies verduidelik en allegories verstaan. René Descartes begin toe sy Discours de la Méthode met ' $\mathrm{n}$ bespreking van die Euklidiese wiskunde as synde die epistemologiese basis vir alle verstaan van die werklikheid. En in die 17e eeu - na Kopernikus, Galilei en Kepler - word ruimte dan verstaan as ' $n$ kontinue en onbegrensde uitgebreidheid wat matematies voorgestel en empiries gekalibreer word. Tyd het ook nie stilgestaan nie. Met die ontdekking van die veer (ongeveer die begin van die 16e eeu) het die sakhorlosie die lig gesien en het tyd gefragmenteerd geraak en verloor dit sy begin, doel en sin. Tyd word ook van ruimte losgemaak en ewige onveranderlikes ontstaan. Dit het uiteraard uitwerking gehad op ons verstaan van liggaamlikheid, materie en substansie. Waar betekenis aanvanklik in terme van die konteks of netwerk van bestaan verstaan is, word dit met die Renaissance geïsoleer en van alle metafisiese dimensies ontdaan. Anders as waarvan Aquinas oortuig was, is die letterlike 
betekenis losgemaak van die allegoriese en geestelike betekenis (corpus mysticum) en is ' $n$ liggaam bloot ' $n$ disparate entiteit. Die betekenisverandering het ook invloed op taal gehad. Aristoteles se oortuiging dat retorika en logika onskeidbaar is, het in die slag gebly. Tekste, is gemeen, hét betekenis en is onafhanklik van hulle konteks. Hiermee is die modernisme gebore en is God-talk uit die publieke arena uitgehaal. Geloof het dus geen "straatwaarde" meer oorgehou nie. En dit alles het duidelik om 'n korrektief geroep.

Heim identifiseer drie sogenaamde posita van 'n werklikheidsverstaan wat deur die sekularisme aangehang word, maar deur die kwantum-fisika as bygeloof ontmasker is. As " $n$ "genadige katastrofe" het die fisika die een na die ander afgod tot ' $\mathrm{n}$ val gebring (Heim 1951:25). Egte materialisme sê dat niks bestaan buiten atome in ' $n$ leë ruimte nie - die res is blote menings. Slegs atome behou hulle geometriese beskrywings ongeag hulle verbindings. Daarom word ook gemeen dat dit ongeskape en oneindig is. Die tyd en ruimte as omvattende koördinaatsisteem met die archimediese wêreldmiddelpunt waaraan die mens homself oriënteer, is die tweede sekularistiese absolute wat ontmasker moes word. Die natuurlike hunkering van die mens om geanker te wees, het eventueel meegebring dat die wêreldbeeld van Kepler, Galilei en Kopernikus ook vir die kerk aanvaarbaar geword het hierdie wêreldbeeld vertrek immers ook vanaf 'n vastepunt (Heim 1951:69). Derdens het die determinisme die geslotenheid van alle gebeure gepredestineer. Kousaliteitswette van die natuurwetenskap is op die geskiedenis getransponeer en die toekoms het die verlengstuk van die verlede geword.

Die oortuiging het lank bestaan dat die drywende krag in die heelal eter is en dat dit dan die konstante basis van alle syn is. Die ganse ruimte word dan die ruspunt. Twee ontdekkings het egter hierdie gedagte laat sneuwel. Eerstens is besef dat materie nie iets oneindig en weerstandloos kan voortplant nie. Lig sal dus iewers tot stilstand moet kom. Andersyds is besef dat aangesien die aarde beweeg, die gepostuleerde eterstof na voor moet verdig (wet van addisie) en na agter moet verdun (wet van subtraksie). Lig sal dus verskillende snelhede in dieselfde en teenoorgestelde rigtings van die beweging van die aarde moet hê. (Heim 1951:69 ev).

Wanneer mens nou byvoorbeeld Gilles Deleuze se werke lees, is die onderliggende ooreenkoms met Heim se ruimte-begrip merkwaardig. Deleuze (1987:54) wil duidelik induktief te werk gaan in sy poging om die werklikheid te verstaan, en noem homself dan ook ' $n$ empiris. Deur by die dinge self te begin, verduidelik Deleuze metafories (1987:viii, 12, $34,67)$, is om die groei van die risoom met dié van 'n boom te vergelyk. Dis voorhande, sonder begin of end, wortels, hooftakke of sytakke, 
ingebed in die omgewing, altyd die middel, dus simbioties. Dit is ' $\mathrm{n}$ multiplicity wat in kort beteken dit is ' $\mathrm{n}$ versameling lyne of dimensies wat nie inmekaar opgelos kan word nie (Deleuze 1987:vii). Wanneer twee lyne kruis, is daar ' $\mathrm{n}$ punt. Hierdie punte vorm dan die states of things. Maar dit moet nie net op 'n platvlak verstaan word nie, maar driedimensioneel in ' $\mathrm{n}$ voortgaande proses van groei (Sedgwick 2001:137). Die bipolariteit word dus gerelativeer deur die $E N$ daartussen, dit is die intermezzo of die gras (Deleuze 1987:34). Die werklikheid is nou gedeterritorialiseer en ad hoc deur heterogene dele gerealiseer in 'n proses van wording. Daarom is wetenskaplikes toenemend gefokus op besondere gebeure, op nie-liggaamlikheid en op koppelvlakke (Deleuze 1987:67). En $\sin$ is vir hom dan ook die vierde dimensie van 'n proposisie deurdat dit nie is nie, maar word.

Heim se begrip van ruimte is inderdaad bruikbaar nie net vir die filosofie nie, maar ook vir die teologie. Walter Kasper se uiteensetting van die opstanding byvoorbeeld bied ' $n$ duidelike Christologiese toepassing van bogenoemde verstaan. Ek wil dit illustreer met bloot ' $\mathrm{n}$ paar tersaaklike aanhalings uit Kasper (1977:149, 151, 152):

- Resurrection and Exaltation mean: Jesus lives wholly and for ever in God (Rom 6.9f). Raising up to the right hand of God does not therefore imply being spirited away to another-worldly empyrean, but Jesus' being with God, his being in the dimension of God, of his power and glory. It does not mean distance from the world, but a new way of being with us.

- Thus we can finally say what the pneumatic body of the Resurrected is: the totality of the person (not just the soul) that is finally in the dimension of God, that has entered entirely into the Kingdom of God. Corporeality of the Resurrection means then: The whole person of the Lord is finally with God.

- The newness which has come into our sphere through Jesus' arrival with God and through his new coming to us, is traditionally called 'heaven', borrowing from the language of myth. Usually this heaven is imagined as empty space into which Jesus was taken up and into which all saints will move in solemn procession at the end of time. These are more or less mythological ideas: theologically, heaven is the dimension which arises when the creature finally arrives with God.

Heim stel hierdie verstaan van hom as ' $n$ teorie bekend en nie as feite nie; dit is ' $n$ denkmoontlikheid en nie 'n denknoodwendigheid nie. 'n Bopolêre dimensie word immers nie empiries ontsluit nie. En dis presies hier waar die geloof die rede kompleteer: dit gaan om 'n geloofswaarheid, maar dan altyd om 'n redelike geloofswaarheid. Feit is egter dat God nie uit die 
natuur bewys kan word nie. Die rede moet eerstens nooit verbygegaan word in die geloof nie - dit wat die toets van die rede nie kan weerstaan nie, is ook nie die moeite werd om te handhaaf nie (Heim 1960:253). Trouens, die natuurwetenskap moet juis hierdie stap fasiliteer waar die moderne absolutes ontmasker word. Die tweede stap sou dan wees om vir die toekoms in God te beslis - 'n oop toekoms waaraan ék deel (Heim 1949:201). So word ek 'n toekomsmens en word subjektivisme versaak. Geloof is vir Heim skeppingsgeloof en skeppingsgeloof is weer die werklikheid.

\section{Literatuurverwysings}

Abbot, E A [1884] 1998. Flatland. A romance of many dimensions. New York: Penguin.

Barbour, I 2000. When science meets religion. Enemies, strangers or partners? London: SPCK.

Barrow, J D 1994. The origin of the universe. London: Orion House.

Buri, F, Lochmann, J M \& Ott, H 1976. Dogmatik im Dialog. Schöpfung und Erlösung. Bd. 3. Gütersloh: Gerd Mohn.

Deleuze, G 1987. Dialogues. New York: Columbia University.

Gregersen, N H \& Van Huyssteen, J W 1998. Rethinking Theology and Science. Six models for the current dialogue. Grand Rapids: Eerdmans.

Hawking, S 2001. The universe in a nutshell. London: Bantam.

Heim K [1904] 1980. Das Weltbild der Zukunft. Wuppertal: Aussaat.

-, 1926. Glaube und Leben. Gesammelte Aufsätze und Vorträge. Berlin: Furche.

-, 1931. Glaube und Denken. Philosophische Grundlegung einer christlichen Lebensanschauung. Berlin: Furche.

-, 1934. Glaube und Denken. Der evangelische Glaube und das Denken der

Gegenwart 1. Berlin: Furche.

-, 1935. Jesus der Herr. Der evangelische Glaube und das Denken der Gegenwart 2.

Berlin: Furche.

-, 1949. Der christliche Gottesglaube und die Naturwissenschaft. Der evangelische

Glaube und das Denken der Gegenwart 4. Berlin: Furche.

-, 1951. Die Wandlung im Naturwissenschaftliche Weltbild. Der evangelische Glaube und das Denken der Gegenwart 5. Hamburg: Furche.

-, 1952. Weltschöpfung und Weltende. Der evangelische Glaube und das Denken der Gegenwart 6. Hamburg: Furche.

-, 1960. Ich gedenke der vorigen Zeiten. Erinnerungen aus acht Jahrzehnten. Hamburg: Furche.

Kant, [1934] 2000. Critique of Pure Reason. A revised and expanded translation based on Meiklejohn, ed. by Vasilis Politis. London: Everyman.

Kasper, W 1977. Jesus the Christ. London: Burns \& Oates. 
Peters, T [1997] 2000. Theology and the natural sciences, in D F Ford, (ed), The modern theologians. An introduction to Christian theology in the twentieth century, 649-668. Oxford: Blackwell.

Sedgwick, P 2001. Descartes to Derrida. An introduction to European Philosophy. London: Blackwell.

Ward, G (ed) [1997] 2000. The postmodern God. A theological reader. London: Blackwell. 